\title{
Strategi Terjemahan Metafora dalam Novel Bumi Manusia
}

\author{
Rodiyah Harahap *1, Umar Mono ${ }^{2}$, Muhizar Muchtar ${ }^{3}$ \\ e-mail: ${ }^{1}$ rodiyahhrp@gmail.com, ${ }^{2}$ umar.mono@yahoo.co.id, 3 \\ muhizaraswina54@gmail.com \\ 1,2,3 Fakultas Ilmu Budaya \\ Universitas Sumatera Utara
}

\begin{abstract}
Abstrak
Sebagai ungkapan figuratif, metafora mengungkapkan perbandingan antara dua hal secara implisit banyak digunakan dalam komunikasi secara lisan dan tulisan. Penelitian ini terbatas pada analisis metafora dengan merujuk pada terjemahan novel bahasa Indonesia berjudul Bumi Manusia yang diterjemahkan dalam bahasa Inggris. Penelitian ini menggunakan metode deskriptif kualitatif. Penelitian ini bertujuan untuk mengetahui strategi yang diterapkan dalam menerjemahkan metafora dalam novel Bumi Manusia ke dalam bahasa Indonesia. Teori yang digunakan dalam analisis ini adalah teori strategi penerjemahan Larson. Metode pengumpulan data yang digunakan adalah metode simak. Hasil penelitian menunjukkan bahwa dari 91 data yang dianalisis, terdapat 4 strategi yang digunakan dalam terjemahan metafora, yaitu metafora diterjemahkan ke dalam metafora yang sama sebanyak 59 data (65\%), 14 data metafora diterjemahkan ke dalam metafora lain (15\%), 8 data (9\%) metafora diterjemahkan ke dalam bentuk simile, dan 10 data (11\%) metafora yang diterjemahkan ke dalam ungkapan non-figuratif. Di antara strategi tersebut, metafora yang diterjemahkan ke dalam metafora yang sama paling dominan diterapkan oleh penerjemah.
\end{abstract}

Kata kunci-metafora, terjemahan, strategi penerjemahan, bumi manusia

\section{A. PENDAHULUAN}

Bagi sebagian orang, membaca novel lebih menarik daripada menonton film atau drama. Melalui membaca novel pembaca mendapatkan imajinasi, kesenangan, dan kenikmatan tanpa batas karena ada bahasa kiasan dalam novel yang memberikan efek khusus terhadap pembaca. Penulis buku dapat menjelajahi cerita dengan memberikan kata-kata konotatif dan menghibur para pembaca sehingga mereka mendapatkan perasaan novel. Banyak buku ditulis dalam bahasa Inggris dan banyak orang Indonesia tidak menguasai bahasa Inggris dengan baik. 
Penerjemah berperan sangat penting untuk menjembatani kesenjangan karena novel adalah salah satu karya sastra. Penerjemah tidak hanya perlu menerjemahkan maknanya tetapi juga untuk menjaga nilai-nilai estetika cerita dalam novel. Mengalihkan dan memindahkan makna serta memilih padanan kata bukanlah pekerjaan yang mudah bagi seorang penerjemah. Seorang penerjemah harus mampu menggunakan strategi penerjemahan dalam mengalihkan dan memindahkan makna serta memilih padanan kata dari Bahasa Sumber ke dalam Bahasa Sasaran. Sebelum menerjemahkan teks, penerjemah hendaklah mengetahui hasil terjemahan itu untuk siapa (audience design) dan untuk tujuan apa (need analysis), sehingga penerjemah dapat menentukan strategi penerjemahan yang paling tepat untuk dilakukan.

Umumnya, sebuah novel memiliki bahasa kiasan seperti personifikasi, perumpamaan, metafora, metonimi, dll. Salah satu bahasa kiasan adalah metafora. Gibbs (1997) menyatakan "penulis sastra menggunakan metafora untuk melampaui dan memperluas sumber daya linguistik dan untuk memberikan wawasan dan perspektif baru ke dalam pengalaman manusia". Artinya lewat metafora seorang penulis buku mengajak pembaca untuk memikirkan sesuatu selain dari kata-kata tertulis di dalamnya dan juga mencoba memperkaya pemahaman pembaca bahwa salah satu bagian dari cerita mungkin terjadi dalam kehidupan mereka.

Dalam praktik penerjemahan, bahasa figuratif atau kiasan merupakan suatu tantangan yang cenderung sulit bagi penerjemah dalam menerjemahkannya ke bahasa lain khususnya menerjemahkan metafora. Metafora adalah suatu bentuk perluasan makna yang digunakan saat berkomunikasi baik secara lisan maupun tulisan. Metafora dapat menjadi masalah bagi penerjemah karena sangat terkait dengan budaya bahasa sumber. Selain itu, ia membandingkan satu hal dengan yang lain yaitu tanda perbandingan tidak sejelas itu dalam simile karena metafora tidak menggunakan kata-kata seperti, seolah-olah, dll.

Metafora digunakan untuk membuat makna yang dihasilkan dari ujaran seseorang dapat tersampaikan dengan singkat, padat serta berisi dan yang paling penting adalah dapat dimengerti oleh mitra tutur sehingga tercipta kesan dan kepiawaian berbahasa seseorang (Zen, 2014). Menurut Moon dan Knowles (2006:5), metafora adalah bahasa non-literal atau figuratif yang mengungkapkan perbandingan antara dua hal secara implisit. Oleh karena itu, penerjemah harus mengetahui dengan baik makna sebenarnya dari metafora BSu tersebut sebelum menerjemahkannya ke dalam BSa.

Newmark (1998:104) menyatakan masalah penerjemahan yang paling sulit secara khusus adalah penerjemahan metafora: ...the most important particular problem is The translation of metaphor. Kesulitan menerjemahkan metafora pada hakikatnya berkaitan dengan struktur metafora yang bervariatif dan unsur pembangunnya yang kompleks. Newmark (1998:105) mendefinisikan metafora sebagai the figurative word used, which may be one-word, or extended 'over any stretch of language from collocation to the whole ext. Berdasarkan pendapat Newmark, bahasa kiasan yang digunakan pada metafora dapat berupa kata atau kata yang diperluas kepada bentuk bahasa dari kolokasi hingga ke seluruh teks. 
Sebagai sebuah ungkapan bahasa, Selain metafora cenderung mengandung nilai-nilai budaya. Karena itu penerjemahannya hanya dapat dilakukan setelah nilai-nilai budaya yang terkait dengan ungkapan tersebut dipahami. Kendala-kendala yang dihadapi dalam penerjemahan metafora telah memunculkan dua pandangan yang kontradiktif mengenai masalah apakah metafora dapat diterjemahkan atau tidak. Dagut (1987: 25) memaparkan bahwa, tidak sedikit ahli penerjemahan seperti Nida, Vinay dan Darbelnet yang menganggap metafora tidak dapat diterjemahkan. Namun beberapa tokoh seperti Kloepfer dan Reiss menganggap bahwa metafora sebagai suatu ungkapan linguistis, sehingga metafora dapat diterjemahkan. Praktik penerjemahan cenderung mendukung translatibilitas (Translatability) metafora. Hal ini dibuktikan oleh begitu banyaknya puisi yang mengandung berbagai ungkapan metaforis karya penyair kenamaan seperti William Shakespeare, Robert Frost, Langston Hughes, Emily Dickinson, Pablo Neruda dan Li Po berhasil diterjemahkan dengan baik ke dalam berbagai bahasa. Oleh karena itu, meskipun sebagian metafora harus diterjemahkan secara ekstra hati-hati, metafora tetap dapat diterjemahkan sebagai salah satu bentuk ekspresi linguistis.

Jika penerjemah tidak dapat memahami makna metafora dalam teks sumber dan gagal menganalisisnya dengan benar, maka akan terjadi kesalahpahaman. Tidak semua metafora dapat diartikan dengan mudah. Jika metafora diterjemahkan secara harfiah, kata per kata sering terjadi salah pengertian.

Sebagai contoh pada kalimat "dalam tubuhnya mengalir darah pribumi” (Toer, 2019:17). Jika kalimat tersebut diterjemahkan secara harfiah menjadi in his body indigenous blood flowed maka makna metafora yang disampaikan dirasa kurang akurat dalam bahasa Inggris. Hal ini karena kata blood flowed lebih bermakna peredaran darah secara struktur biologis, sementara yang dimaksud dalam kalimat bahasa Indonesia tersebut adalah garis keturunan. Oleh karena itu, terjemahan tersebut dapat dikatakan tidak akurat. Kalimat tersebut akan lebih tepat jika diterjemahkan dengan In his body ran some Native blood. Oleh karena itu, penerjemah harus dapat menggunakan penggambaran metaforik yang sepadan dalam bahasa Inggris.

Dalam sebuah novel, penulis banyak menggunakan metafora agar cerita yang dihasilkan lebih imajinatif dan menarik. Sebagai contoh dalam novel Bumi Manusia yang di tulis oleh Pramoedya Ananta Toer yang terjemahan bahasa Inggris oleh Max Lane, di temukan banyak penggunaan metafora. Judul Bumi Manusia pada novel juga dapat dikatakan termasuk metafora yang ditujukan penulis untuk menjelaskan makna bahwa di dalam novel diceritakan berbagai masalah dan konflik kemanusiaan dan kebudayaan.

Contoh metafora yang terdapat dalam novel Bumi Manusia adalah sebagai berikut:

"Aku dengar kau seorang buaya darat" (hal. 158)

Kalimat di atas di terjemahkan menjadi:

"you're a bit of a crocodile with the ladies" 
"Buaya darat" pada kalimat di atas merupakan metafora yang merujuk pada prilaku pria yang suka mempermainkan wanita. Strategi yang digunakan untuk penerjemahan metafora "buaya darat" yaitu metafora Bsu di terjemahkan menjadi metafora dengan citra yang sama di dalam BSa, yaitu crocodile. Penerjemah menerjemahkan metafora "buaya darat" tidak secara harfiah, namun menerjemahkannya dengan crocodile with the ladies. Hal ini dilakukan penffxerjemah karena metafora 'buaya darat' dalam Bsa sudah dapat dipahami hanya dengan diterjemahkan dengan crocodile with the ladies dalam Bsa.

Metafora "buaya darat" yang diterjemahkan menjadi crocodile menurut Pendapat Larson (1998) termasuk metafora hidup. Metafora hidup adalah metafora yang dibentuk oleh penulis atau pembicara pada saat dia ingin menjelaskan sesuatu yang kurang dikenal dengan membandingkannya kepada sesuatu yang sudah dipahami. Artinya pada dasarnya istilah crocodile tidak digunakan dalam bahasa Inggris, namun penulis membentuknya dengan tujuan menjelaskan maksud dari kata dalam BSu.

Peneliti tertarik untuk meneliti strategi yang digunakan dalam terjemahan metafora pada pada novel ini dalam bahasa Inggris untuk menjadi bahan rujukan dan memperkaya khazanah ilmu pengetahuan bahasa khususnya dalam bidang penerjemahan bahasa Indonesia ke dalam bahasa Inggris. Di samping itu, penelitian ini juga berfokus melihat realisasi penggunaan strategi penerjemahan metafora dalam novel Bumi Manusia karya Pramoedya Ananta Toer dari sisi pengaruhnya terhadap keberterimaan terjemahannya dalam bahasa Inggris. Hal ini berdasarkan fenomena penerjemahan metafora yang telah diuraikan di paragraf sebelumnya, bahwa dipahami suatu buku terjemahan yang sudah diterbitkan tidak menjamin bahwa makna metafora yang telah diterjemahkan sudah berterima dalam BSa. Apabila metafora pada novel BSu tersebut tidak berterima diterjemahkan ke BSa maka dikhawatirkan makna metafora tersebut tidak tersampaikan dengan baik.

Novel dipilih sebagai sumber data penelitian ini karena setelah membaca buku tersebut peneliti menemukan banyak ungkapan metaforis yang layak untuk dikaji dari segi penerjemahan. Selain itu, terdapat beberapa alasan tertentu dalam penentuan novel Bumi Manusia sebagai sumber data antara lain, (1) Ungkpan-ungkapan metaforis yang berkaitan dengan kondisi sosial budaya masyarakat peribumi di era kolonial Indonesia. (2) Kepopuleran novel di seluruh dunia sebagai sumber pengajaran sastra di sekolah (3) Adanya apresiasi positif terhadap novel tersebut.

\section{B. KAJIAN TEORI}

\section{Terjemahan}

Menurut Moentaha (2006:9) ada dua pengertian yang berkaitan dengan kata "terjemahan" yakni proses dan hasil/analisis sintesis. Pertama, terjemahan sebagai proses kegiatan manusia di bidang bahasa (analisis) yang hasilnya merupakan teks terjemahan (sintesis). Kedua, terjemahan hanya sebagai hasil saja dari proses kegiatan manusia itu. Hasil itu disebut teks terjemahan. Jadi, terjemahan adalah jenis transformasi antar bahasa yang berbeda dengan jenis transformasi intrabahasa, yakni transformasi yang terjadi di dalam bahasa itu sendiri, jenis yang terakhir ini disebut juga transportasi terjemahan merupakan 
hubungan nyata yang ada antar teks dalam berbagai bahasa, sedangkan transformasi gramatikal adalah transformasi struktur gramatikal ujaran tanpa mengganti komponenkomponen leksikalnya.

Sementara itu, menurut Munday (2001: 5) pengertian dari penerjemahan ini adalah As changing of an original verbal language into a written text in a different verbal language. Maksud dari teks tersebut adalah bahwa terjemahan merupakan pertukaran bahasa lisan yang original ke dalam teks tertulis dalam sebuah bahasa lisan yang berbeda. Terkait dengan perihal ekuivalensi yang ditetapkan sebagai suatu kata kunci.

Catford (1965:20-21) menyatakan bahwa translation is The replacement of textual material in one language (SL) by equivalent textual material in another language and the term equivalent is a clearly a key term. Pemahaman dari definisi tersebut adalah bahwa suatu penerjemahan merupakan proses pertukaran atau pengalihan suatu teks dari bahasa sumber dengan mencari kesepadanan terdekat ke dalam bahasa sasaran. Meskipun sangat jarang terdapat padanan suatu kata dalam bahasa sumber yang sama dengan arti dalam bahasa sasaran, namun keduanya dapat berfungsi secara ekivalen pada saat keduanya dapat saling dipertukarkan (interchangeable).

Berdasarkan definisi para ahli di atas dapat saya simpulkan bahwa penerjemahan adalah proses peralihan atau pertukaran dari bahasa sumber yaitu bahasa ke dalam bahasa sasaran. Penerjemahan bukanlah suatu hal yang sederhana, melainkan sesuatu yang dapat dikategorikan sebagai sesuatu yang kompleks. Disebut kompleks karena penerjemahan tidak terlepas dari berbagai faktor lain yang terkait dengan linguistik, seperti faktor budaya misalnya.

\section{Definisi Metafora}

Metafora adalah sebuah kata atau frasa dengan arti yang bukan sebenarnya menggunakan satu objek atau tindakan untuk mendiskripsikan sebuah konsep dengan sangat jelas Pernejemahan adalah pengganti dari wujud tekstual suatu bahasa (bahasa sumber) ke wujud tekstual yang ekuivalen dalam bahasa lain (bahasa target) (Newmark, 1988:284).

Metafora adalah salah satu artefak budaya yang mengandung nilai-nilai dan melibatkan konseptualisasi dari suatu wilayah untuk merepresentasikan sesuatu yang lain. Proses ini diberi istilah mapping. Oleh karena itu, metafora merupakan penerapan dari sebuah satuan konseptual ke satuan satuan konseptual yang lainnya. (Tobing, 2013)

Alwi dkk (2010:484) menyatakan bahwa metafora ialah cara menyatakan sesuatu dengan memakai kata atau frasa yang artinya berbeda benar dari arti yang biasa. Ungkapan memerangi kebodohan, umpamanya, merupakan hubungan metaforis antara verba memerangi dan nomina kebodohan karena kebodohan dianggap sebagai musuh. Metafora disebutkan oleh Keraf (1994:139) merupakan semacam analogi yang membandingkan dua hal secara langsung, tetapi dalam bentuk singkat: bunga bangsa, buaya darat, buah hati, cindera mata, dan sebagainya. 
Lakoff dan Johnson (1980:3) melihat metafora bukan sekadar fenomena bahasa, melainkan juga melibatkan pikiran dan tindakan manusia: ... metaphor is pervasive in everyday life, not just in language but in thought and action. Our ordinary conceptual system, in terms of which we both think and act is fundamentally methaporical in nature. Metafora diperoleh dan dimengerti secara kognitif oleh manusia berdasarkan pengalaman hidup sehari-hari yang diungkapkan melalui bahasa.

Berdasarkan definisi para ahli di atas dapat disimpulkan bahwa pengertian metafora adalah semua bentuk bahasa baik kata, frasa atau kalimat yang tidak merujuk pada arti sebenarnya bergeser dari makna sebenarnya, namun kalau di pikir secara mendalam masih ada kaitannya dengan makna sebenarnya.

\section{Jenis-Jenis Metafora}

Larson (1998: 274-275) membedakan metafora ke dalam dua kelompok: metafora mati (dead metaphor) dan metafora hidup (live metaphor). Metafora mati merupakan bagian dari konstruksi idiomatis dalam leksikon sebuah bahasa. Ketika sebuah metafora mati digunakan, pendengar atau pembaca tidak memikirkan makna literal kata-kata pembentuknya, tetapi langsung memikirkan makna idiomatik ungkapan tersebut secara langsung. Sebagai contoh, ketika mendengar metafora berbentuk idiom 'kaki meja', pendengar tidak perlu memikirkan makna kata kaki dan meja secara terpisah untuk memahami metafora tersebut.

Metafora hidup adalah metafora yang dibentuk oleh penulis atau pembicara pada saat dia ingin menjelaskan sesuatu yang kurang dikenal dengan membandingkannya kepada sesuatu yang sudah dipahami. Berbeda dengan metafora mati yang sudah lama digunakan sehingga kesan metaforisnya tidak begitu menonjol, kesan metaforis metafora hidup terasa sangat kental setelah perbandingan antar dua hal dalam ungkapan tersebut dipahami dengan baik. Metafora hidup sering digunakan untuk menarik minat pembaca atau pendengar, karena jika ungkapan yang didengar atau dibaca tidak sesuai dengan pola makna yang biasa, seorang pendengar atau pembaca akan dipaksa untuk berpikir keras tentang makna ungkapan tersebut, penggunaannya,

\section{Fungsi Metafora}

Metafora sering digunakan dalam komunikasi sehari-hari untuk memperkenalkan konsep baru dalam penawaran makna yang lebih tepat. Namun ungkapan ini lebih sering digunakan dalam karya sastra yang berbentuk puisi. Selain untuk memperkenalkan sebuah fenomena baru dalam berkomunikasi, metafora digunakan untuk mengungkap makna secara singkat dan padat serta sekaligus menghadirkan efek puitis dalam sebuah karya sastra.

Metafora adalah bahasa kiasan yang umum diucapkan dalam berbagai bahasa. Tentu saja, penulis menggunakan metafora dalam karya-karyanya (biasanya dalam bentuk karya seni seperti puisi, cerita dongeng, novel, dan lainnya) dengan berbagai tujuan. Sejalan dengan fungsi metafora, Newmark (1988: 292) menyatakan ada tiga fungsi metafora, yaitu: 
1. Untuk menggambarkan entitas (benda atau orang), peristiwa, kualitas, konsep atau tindakan secara lebih komprehensif dan padat dari pada menggunakan bahasa harfiah.

2. Fungsi pragmatik (estetis) atau konotatif yaitu untuk mengungkapkan makna, menarik minat pembaca, mengklarifikasikan sesuatu, menyenangkan pembaca atau memberikan kejutan pada pembaca.

3. Hal ini juga digunakan untuk menunjukkan kemiripan antara dua kurang lebih objek yang berbeda.

\section{Strategi Penerjemahan Metafora}

Strategi penerjemahan adalah langkah-langkah yang digunakan dalam memecahkan masalah-masalah penerjemahan. Lörscher dalam Silalahi (2012) mendefinisikan strategi penerjemahan sebagai prosedur yang digunakan penerjemah dalam memecahkan masalah. Oleh karena itu, strategi penerjemahan dimulai dari disadarinya permasalahan dan diakhiri dengan dipecahkannya permasalahan atau disadarinya bahwa masalah tersebut tidak dapat dipecahkan pada titik waktu tertentu. Karena metafora merupakan bentuk ungkapan yang paling sulit diterjemahkan, beberapa ahli mencoba merumuskan strategi khusus untuk menerjemahkannya. Ahli penerjemahan yang pertama kali berkontibusi secara signifikan bagi penerjemahan metafora adalah Dagut, Newmark dan Larson.

Menerjemahkan sebuah metafora tidak lepas dari menerjemahkan budaya yang satu ke dalam budaya yang lain. Larson (1998:137) mengatakan bahwa salah satu problem tersulit dalam penerjemahan adalah perbedaan kebudayaan. Kesulitan yang dihadapi penerjemah dalam hubungannya dengan metafora dikarenakan biasanya penerjemah tidak memperhatikan aspek dan konsep metafora. Metafora selalu menjadi problem dalam penerjemahan karena tidak dapat diterjemahkan secara literal.

Dalam bukunya Meaning-Based of Translation, Larson (1998:293) mengatakan jika metafora diterjemahkan kata per kata, maka hasil terjemahannya akan mengandung banyak kesalahan persepsi. Masalah utamanya dikarenakan konsep budaya yang terkandung dalam metafora Bsu tidak sama dengan budaya Bsa. Lebih lanjut lagi, Lason (1984:276) mengatakan ada beberapa alasan metafora sulit diterjemahkan dan tidak dapat diterjemahkan secara literal. Alasan-alasan itu dirinci sebagai berikut: (1) citra metafora tidak dikenal dengan oleh bahasa sasaran, (2) topic metafora tidak jelas, (3) titik kemiripan metafora bersifat multitafsir, dan (4) frekuensi pemakaian dan penciptaan metafora berbeda-beda pada masing-masing bahasa.

Tujuan penerjemahan adalah mengekspresikan atau menyampaikan kembali isi dan pesan sesuai dengan makna dan gaya bahasa dari Tsu ke Tsa. Oleh karena itu, pemahaman yang mendalam (fluency) akan BSu dan BSa dan juga pemahaman konteks budaya dari kedua bahasa yang digunakan sangat dibutuhkan. Dalam proses terjemahan metafora, pertama-tama kemiripan dari BSu dan BSa perlu dilihat. Dalam beberapa budaya, metafora bahasa Inggris 'He is my little monkey' diterjemahkan secara berbeda-beda. Dalam bahasa 
Inggris, kalimat itu bermakna 'Dia adalah anak kesayanganku'. Sementara itu, dalam bahasa Indonesia terdapat kemungkinan metafora tersebut akan diterjemahkan menjadi.'Dia adalah monyet kecil peliharaanku' atau 'Dia adalah anak kecilku yang nakal'. Hal ini dikarenakan konotasi monkey atau monyet dalam bahasa Indonesi sesuatu yang negatif.

Selanjutnya Larson (1998: 278-279) membagi strategi penerjemahan metafora menjadi lima cara, yaitu (1) menerjemahkan metafora BSu menjadi metafora yang sama di dalam BSa, (2) menerjemahkan metafora BSu menjadi sebuah simile, (3) menerjemahkan metafora BSu menjadi metafora lain dalam BSa tapi memiliki makna yang sama dengan metafora BSu tersebut, (4) menerjemahkan metafora BSu menjadi metafora yang sama di dalam BSa yang disertai dengan penjelasan tentang makna metafora tersebut dan (5) menerjemahkan metafora menjadi ungkapan non-metaforis.

Tabel 1. Panduan Strategi Penerjemahan Metafora berdasarkan Teori Larson

\begin{tabular}{ll}
\hline Bahasa Sumber & Bahasa Sasaran \\
\hline 1. Metafora & 1. Metafora \\
& $\begin{array}{l}\text { a. Jika metafora dalam bahasa Inggris sudah dikenal } \\
\text { masyarakat Indonesia, metafora tersebut cukup } \\
\text { diterjemahkan dengan bahasa literal. }\end{array}$ \\
& $\begin{array}{l}\text { b. Jika ada metafora yang sepadan dalam Bsa, } \\
\text { metafora yang sepadan dalam Bsa dapat digunakan. }\end{array}$ \\
\hline 2. Metafora & $\begin{array}{l}\text { 2. Simile } \\
\text { Indonesia kata 'seperti' dan 'bagaikan' }\end{array}$ \\
\hline 3. Metafora & $\begin{array}{l}\text { 3. Diterjemahkan berdasarkan makna yang sama atau } \\
\text { memparafrase. }\end{array}$ \\
\hline
\end{tabular}

\section{METODE PENELITIAN}

Penelitian ini merupakan penelitian deskriptif-kualitatif yang menjawab masalah penerjemahan metafora pada Teks Sumber (TSu) ke dalam Teks sasaran (TSa) secara kualitatif. Penelitian ini berorientasi pada produk terjemahan, yaitu penelitian yang memusatkan perhatiannya pada hasil terjemahan dan bukan proses terjemahan. Dalam penelitian ini, tataran yang dikaji berupa kata atau frasa yang mengandung ungkapan metaforis dalam suatu kalimat.

Sumber data adalah novel Bumi Manusia dalam bahasa Indonesia yang ditulis Pramoedya Ananta Toer dan terjemahannya dalam bahasa Inggris oleh Inggris Max Lanne. 
Novel versi bahasa Indonesia terdiri atas 534 halaman yang diterbitkan oleh PT Mizan Pustaka. Sedangkan novel terjemahan dalam bahasa Inggris yang diterbitkan oleh the Penguin Group terdiri atas 367 halaman dalam bentuk e-book (pdf) diunduh pada halaman https://epdf.pub/this-earth-of-mankind-buru-quartet.html.

Data yang dipakai adalah terjemahan kalimat dalam bahasa Inggris dengan ungkapan metaforis pada Novel Bumi Manusia (This Earth of Mankind) yang terdiri atas 20 bab. Data terpakai yang digunakan dalam penelitian ini berjumlah 91 kalimat yang mengandung kata atau frasa metaforis.

Data dikumpulkan dengan teknik simak dan catat. Teknik ini digunakan karena sumber yang digunakan adalah sumber tertulis sehingga harus dipahami dengan simak dan dicatatkan kembali untuk kemudian dilakukan pengkodean pada data (Sutopo, 2006). Data yang terkumpul diklasifikasikan dan dianalisis berdasarkan teori Larson (1998: 279-280) tentang strategi terjemahan metafora, dan dibandingkan dengan terjemahan masing-masing dalam bahasa Inggris. Novel Bumi Manusia dipilih sebagai sumber data karena memiliki banyak ungkapan metaforis yang layak untuk dikaji dari segi penerjemahan.

\section{HASIL DAN PEMBAHASAN}

\section{Hasil}

Temuan data berupa kata, frasa atau kalimat metafora yang diterjemahkan dari bahasa Indonesia ke dalam bahasa Inggri pada novel Bumi Manusia adalah sebanyak 94 data. Dari hasil analisis data ditemukan 94 metafora dalam novel Bumi Manusia karya Pramoediya Ananta Toer yang diterjemahkan oleh Max Lane. Metafora-metafora tersebut terdiri atas 4 (empat) strategi strategi penerjemahan, yaitu (1) metafora yang diterjemahkan menjadi metafora dengan citra sama, (2) metafora yang diterjemahkan menjadi metafora dengan citra beda, (3) metafora yang diterjrmahkan menjadi simile, dan (4) metafora yang diterjemahkan menajdi non figuratif. Data sebanyak 94 buah yang diperoleh akandianalisis berdasarkan 2 kategori yaitu analisis kesepadanan makna dan analisis strategi penerjemahan metafora. Analisis strategi penerjemahan metafora menggunakan teori metafora yang dikemukan oleh Larson (1984).

Berdasarkan penelitian yang dilakukan, diidentifikasi terdapat 59 data metafora $\mathrm{BSu}$ menjadi metafora yang sama di dalam BSa (disingkat menjadi $\mathrm{M} \rightarrow \mathrm{M}$ sama), 8 data metafora $\mathrm{BSu}$ menjadi simile $(\mathrm{M} \rightarrow$ Simile $), 14$ metafora BSu menjadi metafora lain dalam BSa tapi memiliki makna yang sama $(\mathrm{M} \rightarrow \mathrm{M}$ citra beda), dan 10 data metafora menjadi ungkapan non- figuratif $(\mathrm{M} \rightarrow$ Non-Figuratif).

Agar diperoleh kesamaan persepsi, perlu dijelaskan bahwa lambang panah\| $(\rightarrow)$ yang digunakan disini bermakna diterjemahkan menjadi, sesuai dengan konteks penggunaannya.

Tabel 2. Jumlah Strategi Penerjemahan Metafora Novel Bumi Manusia 


\begin{tabular}{|c|c|c|c|}
\hline No & Penerjemahan & Jumlah data & Persentasi (\%) \\
\hline 1 & $\mathrm{M} \rightarrow \mathrm{M}$ (citra sama) & 59 & $65 \%$ \\
\hline 2 & $\mathrm{M} \rightarrow \mathrm{M}$ (citra beda) & 14 & $15 \%$ \\
\hline 3 & $\mathrm{M} \rightarrow$ simile & 8 & $9 \%$ \\
\hline 4 & $\mathrm{M} \rightarrow$ non-figuratif & 10 & $11 \%$ \\
\hline Total & & 91 & $100 \%$ \\
\hline
\end{tabular}

Hasil data menunjukkan bahwa strategi yang paling dominan digunakan adalah $\mathrm{M} \rightarrow \mathrm{M}$ (citra sama) sebanyak $65 \%$. Peneliti menyimpulkan bahwa penggunaan strategi $\mathrm{M} \rightarrow \mathrm{M}$ (citra sama) karena kebanyakan metafora tersebut masih dapat dipahami oleh penutur BSa jika diterjemahkan menjadi metafora yang sama seperti metafora "bagian-bagian hutan yang bermandikan sinar perak" diterjemahkan menjadi "Clumps of forest washed with silver rays of sunshine"' (hlm. 22). Strategi $\mathrm{M} \rightarrow \mathrm{M}$ (citra beda) di posisi ke dua sebanyak 15\%. Penerjemah menggunakan strategi $\mathrm{M} \rightarrow \mathrm{M}$ (citra beda) dikarenakan penggunaan metafora tersebut tidak lazim dalam BSa serta adanya perbedaan budaya antara BSu dan BSa dalam penggunaan metafora tersebut. Jika penerjemah menerjemahkan metafora tersebut secara harfiah maka akan terjadi kesalah pahaman. Contoh penggunaan strategi ini terdapat pada metafora "mata keranjang" yang diterjemahkan menjadi "lady killer" (hlm. 23) dan metafora "tindakannya yang menjilat dan merugikan" yang diterjemahkan menjadi His crawling behavior (hlm. 116). Strategi M $\rightarrow$ Simile sebanyak 8\%. Strategi ini digunakan apabila metafora tersebut lebih mudah dipahami dalam bentuk simile daripada tetap mempertahankannya dalam bentuk metafora. Contoh penggunaan strategi ini adalah metafora "Tuan melemma yang sebesar gajah itu" diterjemahkan menjadi "Mr. Mellema, as big as an elephant," (hlm. 52). Strategi M $\rightarrow$ Non-Figuratif sebanyak 11\%. Strategi M $\square$ Non-Figuratif digunakan karena BSa tidak memiliki ungkapan yang sepadan dengan metafora BSu contoh "dan kaki pun jadi salah tingkah" menjadi "and my feet tripped" (hlm. 51). Untuk memperjelas hasil temuan ditampilkan juga sebuah diagram, seperti berikut. 


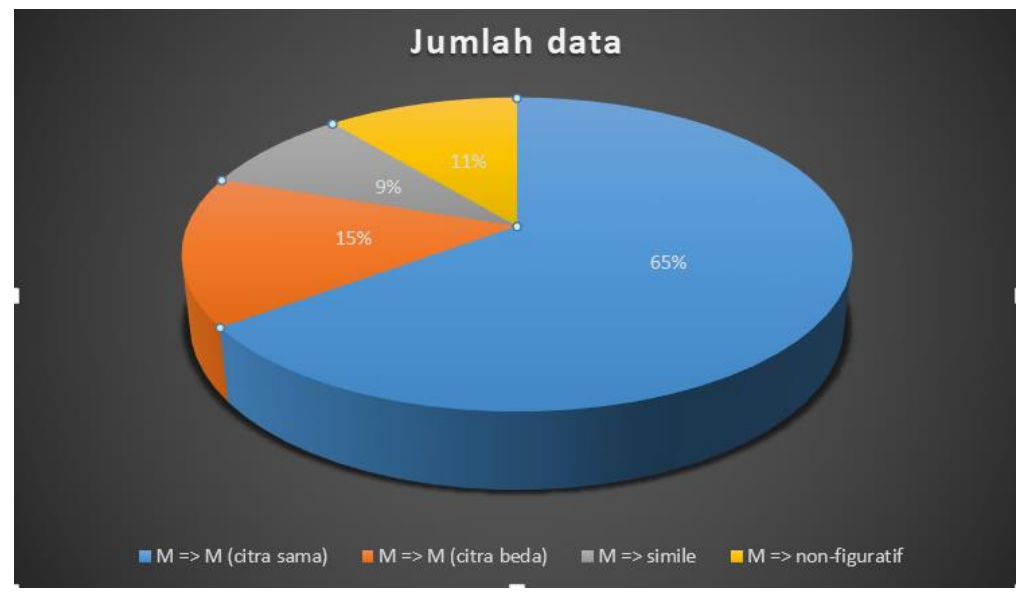

Gambar 1. Diagram perbandingan jumlah persentase strategi penerjemahan metafora novel Bumi Manusia

\section{Pembahasan}

Dalam Penerjemahan metafora yang diterjemahkan menjadi metafora, dibagi kembali menjadi 2 jenis strategi penerjemahan, yaitu metafora yang diterjermahkan menjadi metafora dengan citra yang sama dan metafora yang diterjemahkan menjadi metafora dengan citra yang berbeda.

\section{a. Metafora Menjadi Metafora dengan Citra yang Sama}

Penerjemahan metafora dapat berbentuk pemertahanan bentuk ekspresi metafora dalam TSa. Hal ini dapat dilakukan jika terjemahan metafora masih terasa wajar dan jelas maknanya bagi pembaca dalam TSa. Strategi ini tepat sekali jika digunakan untuk menerjemahkan metafora yang memiliki citra universal. Strategi ini sejalan dengan pendapat Newmark (1988: 107) tentang citra universal yang menurutnya diungkapkan dengan katakata universal tentang ruang, waktu, bagian tubuh, unsur ekologi dan aktivitas manusia yang dikenal hampir semua orang. Kata-kata universal ini merupakan ciri metafora mati. Mengalihkan metafora ke metafora yang sama dengan menggunakan citra yang sama dalam bahasa sasaran. Berikut contoh yang dalam data yang memperlihatkan penerjemahan metafora ke metafora.

(1) TSu :Dalam hidupku, baru seumur jagung, sudah dapat kurasai

TSa: I was still very young, just the age of a corn plant

(Halaman 4)

Metafora dalam kalimat (1) terdapat dalam Bab 1 halaman 4. Pada kalimat (1) terdapat metafora 'seumur jagung' yang diterjemahkan dengan 'I was still very young, just the age of a corn plant.' Metafora 'seumur jagung' diungkapkkan oleh Minke sebagai ungkapan merendahkan diri untuk menjelaskan perihal dirinya dalam prolog cerita. Seorang pemuda yang belum banyak memiliki pengalaman hidup. 
Pada kalimat (1) penerjemah menggunakan strategi penerjemahan metafora 'seumur jagung' dengan mengubahnya ke dalam metafora dalam BSa dengan citra yang sama, yaitu citra universal 'umur jagung.' Dengan kata lain pembaca dapat memahami pesan yang terdapat dalam metafora tersebut sebagaimana pembaca Bsu memahami metafora aslinya dalam Tsu. Kata 'seumur jagung' jika dipetakan dalam unsur-unsur sifat yang muda, belum berpengalaman, dan masih awam. Ketika orang menggunakan kata seumur jagung maka mengasosiasikannya dengan penampilan fisik muda, lugu dan sikap awam, belum berpengalaman. Persamaan ini menunjukkan bahwa terjemahan dapat diterima ke dalam bahasa sasaran. Dari pengalihan ini nampak penerjemah berusaha mempertahankan menjadi metafora yang sama.

(2) TSu : ..di kejauhan sana samar-samar nampak gunung-gemunung berdiri tenang dalam keangkuhan,..

TSa : ..far away in the distance, indistinctly visible, were the mountains, standing silent in their arrogance,...

(Halaman 23)

Metafora dalam Kalimat (2) terdapat dalam Bab 1 halaman 23. Pada kalimat (2) terdapat metafora 'gunung-gemunung berdiri tenang dalam keangkuhan' yang diterjemahkan dengan 'the mountains, standing silent in their arrogance.' Metafora ini diungkapkan oleh Minke sebagai ungkapan kekesalan Minke pada Robert yang merendahkannya, sehingga pemandangan gunung yang dia lihat dari dalam rumah Annielies ia gunakan untuk menjelaskan keadaan perasaannya.

Pada kalimat (2) penerjemah menggunakan strategi penerjemahan metafora 'gununggemunung berdiri tenang dalam keangkuhan' dengan mengubahnya ke dalam metafora dalam BSa dengan citra yang sama, yaitu citra universal 'gunung yang berdiri tegak.' Tegaknya gunung menggambarkan sikap arogansi Robert yang dirasakan Minke dalam situasi tersebut. Oleh karena itu, pembaca dapat memahami pesan yang terdapat dalam metafora tersebut sebagaimana pembaca Bsu memahami metafora aslinya dalam Tsu. Dengan kata lain, ini menunjukkan bahwa terjemahan dapat diterima ke dalam bahasa sasaran. Dari pengalihan ini nampak penerjemah berusaha mempertahankan menjadi metafora yang sama.

(3) TSu : Jean sedang tenggelam dalam lukisannya.

TSa : He was, as usual, absorbed in his drawings,

(Halaman 54)

Metafora dalam kalimat (3) terdapat dalam Bab 3 halaman 54. Pada kalimat (2) terdapat metafora 'tenggelam dalam lukisannya' yang diterjemahkan dengan 'absorbed in his drawings.' Metafora 'tenggelam dalam lukisannya' diungkapkkan oleh Minke yang melihat 
Jean sedang fokus melukis di pinggir sungai. Jean adalah teman Minke yang merupakan pria berdarah Eropa yang juga memiliki Istri Pribumi. Jean memiliki hobi melukis ditemani anaknya.

Pada kalimat (3) penerjemah menggunakan strategi penerjemahan metafora 'tenggelam dalam lukisannya' dengan mengubahnya ke dalam metafora dalam BSa dengan citra yang sama, yaitu citra universal 'fokus' sehingga tidak menyadari lingkungan sekitar, dalam hal ini keberadaan Minke yang ada di dekatnya. Kata tenggelam memberikan gambaran keadaan hening dan tanpa sadar dalam satu aktivitas pekerjaan.

Penerjemahan kata 'tenggelam' menjadi 'absorbed' yang bermakna 'terserap' meskipun secara harfiah tidak sama, namun memiliki citra yang sama. Oleh karena itu, pembaca dapat memahami pesan yang terdapat dalam metafora tersebut sebagaimana pembaca Bsu memahami metafora aslinya dalam Tsu. Dengan kata lain, ini menunjukkan bahwa terjemahan dapat diterima ke dalam bahasa sasaran. Dari pengalihan ini nampak penerjemah berusaha mempertahankan menjadi metafora yang sama.

\section{b. Metafora yang diterjemahkan menjadi metafora dengan citra yang berbeda}

Metafora lain bermakna sama yang dimaksud dalam penelitian ini yaitu mencari padanan metafora yang dikenal dalam Bsu atau dengan cara mengubah citra metafora dalam bahasa sumber menjadi citra yang sudah dikenal dalam bahasa sasaran dan bermakna sama. Cara ini dilakukan sebagai usaha menjembatani perbedaan budaya Bsu dan Bsa. Ditinjau dari akibat penerapan strategi ini, meskipun metafora dalam Bsu berbeda dengan metafora dalam Bsa secara leksikal, kedua metafora ini memiliki makna yang sama. Berikut ini contoh metafora yang dialihkan ke metafora lain yang bermakna sama.

(4) TSu : Ahoi, si philogynik, mata keranjang, buaya kita ! Bulan mana pula sedang kau rindukan.

TSa : Hey, philogynist, lady-killer, crocodile, where is your harem?

(Halaman 23)

Metafora dalam kalimat (4) terdapat dalam Bab 3 halaman 23. Terdapat 2 metafora yang memiliki citra yang berbeda, yaitu 'Mata keranjang' dan 'bulan mana yang sedang kau rindukan' yang diterjemahkan dengan 'lady-killer' dan 'where is your harem?' Metafora 'mata keranjang' dan 'bulan mana yang sedang kau rindukan' diungkapkkan oleh Robert saat masuk begitu saja dan melihat Minke sedang melamun di kamarnya.

Pada kalimat (4) penerjemah menggunakan strategi penerjemahan metafora 'mata keranjang' dan 'bulan mana yang sedang kau rindukan' dengan mengubahnya ke dalam metafora dalam BSa dengan citra yang berbeda. Mata keranjang memberikan citra lelaki yang suka melihat perempuan yang cantik, berbeda dengan kata 'lady killer' bercitra seorang pria yang dapat menaklukkan lelaki, Sedangkan metafora 'bulan mana yang sedang kau rindukan' memberikan citra perempuan bagaikan bulan dan dalam terjemahannya kata 'harem' bercitrakan selir-selir di sebuah kerajaan. 
Penerjemahan kata 'mata keranjang' dengan padanan 'lady-killer' yang bermakna 'penakluk wanita' dan 'bulan mana yang sedang kau rindukan' dengan padanan 'where is your harem?' secara harfiah tidak sama dan memiliki citra yang berbeda. Meskipun berbeda citra, terjemahan tersebut masih pembaca dapat memahami pesan yang terdapat dalam metafora tersebut sebagaimana pembaca Bsu memahami metafora aslinya dalam Bsu. Dengan kata lain, ini menunjukkan bahwa terjemahan dapat diterima ke dalam BSa. Dari pengalihan ini nampak usaha penerjemah merubah metafora dalam BSu kedalam padanan metafora dalam BSa dengan citra berbeda untuk bisa dimengerti pembaca.

(5) TSu : Tindakannya yang menjilat dan merugikan teman-temannya menjadikannya tersisih dari pergaulan

TSa : His crawling behavior, which often harmed his friends, caused him to be cut off from society

(Halaman 80)

Pada kalimat (5) terdapat dalam Bab 5 halaman 80. Terdapat terjemahan metafora ke metafora yang memiliki citra yang berbeda, yaitu 'tindakannya yang menjilat' yang diterjemahkan dengan 'his crawling behavior.' Metafora 'tindakannya yang menjilat' adalah anggapan Minke terhadap para pejabat-pejabat di lingkungannya.

Penerjemah pada kalimat (5) digunakan strategi penerjemahan metafora 'tindakannya yang menjilat' dengan mengubahnya ke dalam metafora dalam BSa dengan citra yang berbeda. 'menjilat' memberikan citra yang merujuk pada alat pengecap yaitu lidah, berbeda dengan kata 'crawling' bercitra keadaan tubuh merangkak.

Penerjemahan kata 'his crawling behavior' sebagai padanan dari 'tindakannya yang menjilat' menunjukkan bahwa terjadi penerjemahan yang memiliki citra yang berbeda. Meskipun berbeda citra, terjemahan tersebut pembaca masih dapat memahami pesan yang terdapat dalam metafora tersebut sebagaimana pembaca Bsu memahami metafora aslinya dalam Bsu. Dengan kata lain, ini menunjukkan bahwa terjemahan dapat diterima ke dalam BSa. Dari pengalihan ini nampak usaha penerjemah merubah metafora dalam BSu kedalam padanan metafora dalam BSa dengan citra berbeda untuk bisa dimengerti pembaca.

\section{Penerjemahan metafora menjadi simile}

Seorang penerjemah dapat mengalihkan metafora menjadi simile. Dengan demikian, metafora dapat dengan mudah diterjemahkan dan memperlancar proses penerjemahan. Larson (1998) menjelaskan strategi ini dapat dilakukan dengan menggunakan konjungsi like 'seperti' dan as 'bagaikan' untuk mengekspresikan perbandingan antara topik dan citra. Berikut ini adalah contoh data metafora yang dialihkan menjadi simile ke dalam Tsa.

(6) TSu : Rasanya ada gendang bermain dalam jantungku

TSa : It felt as if a drum were pounding in my heart 
(Halaman 26)

Metafora dalam kalimat (6) terdapat dalam Bab 2 halaman 23. Terdapat metafora yang diterjemahkan ke dalam simile yang ditandai dengan konjungsi ' $a s$ ' dalam kalimat as if a drum were pounding in my heart yang berarti '(bagaikan) ada gendang bermain dalam jantungku'. Metafora yang diterjemahkan menjadi simile ini diungkapkkan oleh Minke saat bertamu ke rumah Nyai Ontoroso dan melihat Annelies yang keluar menyambutnya sebagai tamu.

Pada kalimat (6) penerjemah menggunakan strategi penerjemahan metafora 'gendang bermain di Jantung' dengan mengubahnya ke dalam simile dalam BSa dengan citra yang sama. Konjugasi as memberi makna 'seperti' atau 'bagaikan' yang menjadi penanda simile dalam Bsa. Citra dalam metafora yang merujuk pada perasaan resah dan gugup yang digambarkan melalui gendang yang berdegub juga digunakan sama pada terjemahan simile. Oleh karena itu, tergambarkan bahwa terjemahan dapat diterima ke dalam bahasa sasaran.

(7) BSu : Selama pembicaraan semua terasa timbul-tenggelam dalam lautan.

BSa : During the conversation everything felt as if it were surging and then falling again like the ocean.

(Halaman 84)

Metafora dalam kalimat (7) terdapat dalam Bab 3 halaman 84. Terdapat metafora yang diterjemahkan ke dalam simile yang ditandai dengan konjungsi 'like' dalam kalimat surging and then falling again like the ocean yang berarti 'timbul-tenggelam (seperti) dalam lautan'. Metafora yang diterjemahkan menjadi simile ini diungkapkkan oleh Minke dalam perasaannya ketika melihat percakapan antara ayahnya dan para pembesar dari daerah Melayu. Bahasa yang mereka gunakan sulit dimengerti oleh Minke sehingga minke mengungkapkan suara dalam pembicaraan dengan metafora 'timbul tenggelam dalam lautan.'

Kalimat (7) menunjukkan penerjemah menggunakan strategi penerjemahan metafora ke dalam simile dalam BSa dengan citra yang sama. Konjugasi like memberi makna 'seperti' atau 'seolah-olah' yang menjadi penanda simile dalam Bsa. Citra dalam metafora yang merujuk pada keadaan suara percakapan orang-orang dalam bahasa yang tidak dimengerti seolah-olah "dalam lautan" juga digunakan sama pada terjemahan simile. Oleh karena itu, tergambarkan bahwa strategi terjemahan ini dapat diterima pembaca dalam BSa.

\section{Penerjemahan metafora menjadi non figuratif}

Dalam strategi penerjemahan metafora menjadi bentuk non-figuratif, digunakan ketika citra terjemahan dalam Bsa dialihkan ke dalam metafora yang sama tetapi maknanya sulit dipahami. Selain itu, strategi ini dapat juga diterapkan jika tidak terdapat ungkapan metafora yang sepadan di dalam Bsa. Penerjemahan dengan menggunakan strategi ini dapat dilakukan dengan mengalihkan citra metafora Bsu menjadi ungkapan bahasa sehari-hari. Strategi penerjemahan ini sangat tepat digunakan ketika menerjemahkan metafora mati atau metaforis idiom. Bahasa yang digunakan untuk mengalihkan metafora jenis ini biasanya 
bahasa sehari-hari yang singkat, sederhana, dan luwes, serta mudah dipahami oleh pembaca. Data di bawah ini diterjemahkan menggunakan strategi penerjemahan dengan mengalihkan metafora ke dalam ungkapan non-figuratif.

(8) BSu : Saya menjawab membabi buta.

BSa : I answered hotheadedly and recklessly.

(Halaman 138)

Pada kalimat (8) terdapat dalam Bab 7 halaman 138 terdapat metafora yang diterjemahkan menjadi bentuk non-figuratif, yaitu 'membabi buta' yang diterjemahkan dengan 'hotheadedly and recklessly.' Metafora 'membabi buta' adalah ungkapan terkait jawaban Minke terhadap Miriam dan Sarah ketika mereka berbincang tentang guru di HBS.

Penerjemah pada kalimat (8) digunakan strategi penerjemahan metafora 'membabi buta' dengan mengubahnya ke dalam metafora dalam BSa dengan citra yang berbeda. 'Membabi buta' memberikan citra yang merujuk pada prilaku hewan (babi), berbeda dengan kata 'hotheadedly and recklessly' bercitra keadaan suhu dan gegabah atau asal-asalan.

Penerjemahan kata 'mata keranjang' dengan padanan 'lady-killer' yang bermakna 'penakluk wanita' dan 'bulan mana yang sedang kau rindukan' dengan padanan 'where is your harem?' secara harfiah tidak sama dan memiliki citra yang berbeda. Meskipun berbeda citra, terjemahan tersebut masih pembaca dapat memahami pesan yang terdapat dalam metafora tersebut sebagaimana pembaca Bsu memahami metafora aslinya dalam Tsu. Dengan kata lain, ini menunjukkan bahwa terjemahan dapat diterima ke dalam bahasa sasaran. Dari pengalihan ini nampak penerjemah berusaha mempertahankan menjadi metafora yang sama.

(9) BSu : Ahoi, si philogynik, mata keranjang, buaya kita ! Bulan mana pula sedang kau rindukan.

BSa : Hey, philogynist, lady-killer, crocodile, where is your harem?

(Halaman 23)

Metafora dalam kalimat (9) terdapat dalam Bab 3 halaman (23). Terdapat 2 metafora yang memiliki citra yang berbeda, yaitu 'Mata keranjang' dan 'bulan mana yang sedang kau rindukan' yang diterjemahkan dengan 'lady-killer' dan 'where is your harem?.' Metafora 'mata keranjang' dan 'bulan mana yang sedang kau rindukan' diungkapkkan oleh Robert saat masuk begitu saja dan melihat Minke sedang melamun di kamarnya.

Pada kalimat (9) penerjemah menggunakan strategi penerjemahan metafora 'mata keranjang' dan 'bulan mana yang sedang kau rindukan' dengan mengubahnya ke dalam metafora dalam BSa dengan citra yang berbeda. Mata keranjang memberikan citra lelaki yang suka melihat perempuan yang cantik, berbeda dengan kata 'lady killer' bercitra seorang pria yang dapat menaklukkan lelaki, Sedangkan metafora 'bulan mana yang sedang kau 
rindukan' memberikan citra perempuan bagaikan bulan dan dalam terjemahannya kata 'harem' bercitrakan selir-selir di sebuah kerajaan.

Penerjemahan kata 'mata keranjang' dengan padanan 'lady-killer' yang bermakna 'penakluk wanita' dan 'bulan mana yang sedang kau rindukan' dengan padanan 'where is your harem?' secara harfiah tidak sama dan memiliki citra yang berbeda. Meskipun berbeda citra, terjemahan tersebut masih pembaca dapat memahami pesan yang terdapat dalam metafora tersebut sebagaimana pembaca Bsu memahami metafora aslinya dalam Tsu. Dengan kata lain, ini menunjukkan bahwa terjemahan dapat diterima ke dalam bahasa sasaran. Dari pengalihan ini nampak penerjemah berusaha mempertahankan menjadi metafora yang sama.

(10) $\mathrm{BSu}:$ Ia terpencil di lingkungannya sendiri

$\mathrm{BSa}:$ He was isolated in the midst of his own world

(Halaman 138)

Pada kalimat (10) terdapat dalam Bab 5 halaman 80 terdapat metafora yang diterjemahkan menjadi bentuk non-figuratif, yaitu 'Ia terpencil di lingkungannya sendiri' yang diterjemahkan dengan 'He was isolated in the midst of his own world.' Metafora 'Ia terpencil di lingkungannya sendiri' adalah ungkapan Nyai Ontosoro terhadap ayahnya yang merasa ayahnya dikucilkan diantara orang-orang yang kedudukannya lebih tinggi dibandingkan dengan ayahnya.

Penerjemah pada kalimat (10) digunakan strategi penerjemahan metafora 'Ia terpencil di lingkungannya sendiri' dengan mengubahnya ke dalam metafora dalam BSa dengan citra yang berbeda. 'Ia terpencil di lingkungannya sendiri' memberikan citra yang merujuk pada keadaan dan situasi yang dirasa asing pada dirisendiri, kata terpencil yang bermakna metaforis dialihkan dengan kata isolated yang bermakna non-figuratif.

Penerjemahan kata 'terpencil' dengan padanan 'isolated' secara harfiah berbeda tetapi memiliki citra yang sama. Terjemahan tersebut digunakan karena tidak terdapat padanan metafora yang sama dalam BSa sehingga penggunaan bentuk non-figuratif lebih tepat agar terjemahan masih dapat dipahami pembaca dan pesan yang terdapat dalam metafora tersebut sebagaimana pembaca Tsu pahami, sama dengan yang dipahami pembaca dalam Tsa. Dengan kata lain, ini menunjukkan bahwa terjemahan dapat diterima ke dalam bahasa sasaran.

(11) BSu : Orang lain sebagian memandangnya dengan mata sebelah

BSa : Outsiders viewed her as only a nyai, a concubine

(Halaman 23)

Pada kalimat (11) terdapat dalam Bab 4 halaman 72 terdapat metafora yang diterjemahkan menjadi bentuk non-figuratif, yaitu 'memandangnya dengan mata sebelah' yang diterjemahkan dengan 'viewed her as only a nyai, a concubine.' Metafora 
'memandangnya dengan mata sebelah' adalah ungkapan Minke mengenai Nyai Ontosoro yang di anggap rendah dikalangan orang-orang berdarah biru.

Penerjemah pada kalimat (11) digunakan strategi penerjemahan metafora 'memandangnya dengan mata sebelah' dengan mengubahnya ke dalam metafora dalam BSa dengan citra yang berbeda. 'memandangnya dengan mata sebelah' memberikan citra yang merujuk pada keadaan dan situasi yang dirasa asing pada dirisendiri, kata terpencil yang bermakna metaforis dialihkan dengan kata viewed her as only a nyai, a concubine yang bermakna non-figuratif.

Penerjemahan kata 'memandangnya dengan mata sebelah' dengan padanan 'viewed her as only a nyai, a concubine' digunakan karena tidak terdapat padanan metafora yang sama dalam BSa sehingga penggunaan bentuk non-figuratif lebih tepat agar terjemahan masih dapat dipahami pembaca dan pesan yang terdapat dalam metafora tersebut sebagaimana pembaca Tsu pahami, sama dengan yang dipahami pembaca dalam Tsa. Dengan kata lain, ini menunjukkan bahwa terjemahan dapat diterima ke dalam bahasa sasaran.

\section{E. KESIMPULAN}

Kesimpulan dalam penelitian ini adalah terdapat 94 metafora dalam novel Bumi Manusia karya Pramoediya Ananta Toer yang diterjemahkan oleh Max Lane. Metaforametafora tersebut terdiri atas 4 (empat) strategi strategi penerjemahan, yaitu (1) metafora yang diterjemahkan menjadi metafora dengan citra sama sebesar $65 \%$, (2) metafora yang diterjemahkan menjadi metafora dengan citra beda sebesar $15 \%$, (3) metafora yang diterjrmahkan menjadi simile sebesar $9 \%$, dan (4) metafora yang diterjemahkan menajdi nun-figuratif sebesar $11 \%$.

Kemudian penggunaan strategi penerjemahan digunakan dalam penerjemahan metafora pada novel Bumi Manusia karya Pramoedya Ananta Toer bertujuan untuk menjelaskan kata-kata universal yang sudah banyak dikenal orang dari berbagai pengguna bahasa yang berbeda-beda, sulitnya memahami dan menerjemahkan metafora karena citra yang digunakan dalam metafora mungkin tidak lazim dalam BSa, topik metafora yang tidak selalu dinyatakan dengan jelas dan perbedaan kebudayaan antara kedua bahasa.

\section{DAFTAR PUSTAKA}

Alwi, H., dkk. 2010. Tata Bahasa Baku bahasa Indonesia. Jakarta: Balai Pustaka.

Catford, J. C. 1965. A linguistic theory of translation, London: Oxford university press.

Dagut, M. 1987. Can "Metaphor" be Translated ?. Babel: International Journal of Translation, Vol. 22 (1).

Gibbs Jr, R.W. (ed). 1996. Researching Metaphor. Researching and Applaying Metaphor. Cambridge: Cameron, Lynne/Low, Graha. 
Keraf, G. 1994. Diksi dan Gaya Bahasa. Jakarta: PT Gramedia Pustaka Utama.

Lakoff, G. dan Johnson, M. 1980. Metaphors we live by. Chicago, IL: University of Chicago Press.

Larson, M. L. 1989. Penerjemahan Berdasarkan Makna: Pedoman untuk Peadanan Antarbahasa. Kencanawati Taniran, penerjemah. Jakarta: Arcan. Trjemahan dari: Meaning-Based Translation: A Guide to Cross Language Equivalence.

Larson, M. L. 1998. Meaning Based Translation: a Guide to Cross Language Equivalent. Larham: University Pres of America.

Moentaha, S. 2006. Bahasa dan Terjemahan. Jakarta: Kasaint Blanc.

Moon, R. dan Knowles, M. 2006. Introducing Metaphor. New York: Routledge.

Munday, J. 2001. Introducing to Translation Studies: Theories and Applications. London and New York: Routledge.

Newmark, P. 1988. A textbook of translation. New York: Prentice-Hall International.

Newmark, P. 1998. Approaches to translation. Oxford: Pergamon

Silalahi, R., 2012. Terjemahan Teks Medis Dalam Bahasa Indonesia: Analisis Dampak Kemampuan Kualitas Terjemahannya. Medan: Bartong Jaya.

Sutopo, H. B. 2006. Metode Penelitian Kualitatif. Surakarta: UNS Press

Tobing, R. L. 2013. Makna dan Fungsi Metafora Bahasa Batak Toba dan Bahasa Jawa (Kajian Bahasa Dan Budaya. http://staff.uny.ac.id/sites/default/files/131764501/Ungkapan\%20Metafora\%20Bahasa \%20Batak\%20Toba.rtf

Toer, P. A. 2019. Bumi Manusia. Jakarta: Mizan.

Toer, P. A. Translated and with an Afterword by Max Lane. 1996. This Earth of Mankind. New York: The Penguin Group.

Zen, T. R. 2014. Metafora Gramatikal Pada Teks Terjemahan Buku Biologi Bilingual. Medan: Tesis Universitas Sumatera Utara. 